\title{
PRECEDENTES JUDICIAIS E A COMPARAÇÃO LUSO-BRASILEIRA: SEMELHANÇAS E DISTINÇÕES
}

\author{
Francisco de Assis Diego Santos de Souza ${ }^{1}$
}

\section{RESUMO}

O presente artigo tem por escopo trazer ao conhecimento da sociedade acerca da realidade dos sistemas de precedentes judiciais no Brasil e em Portugal, enfatizando em que medida há semelhanças ou distinções entre tais normas. Buscou-se a partir de um método de abordagem dedutivo, com procedimento monográfico e técnicas indiretas de pesquisa esmiuçar a temática, perpassando desde as questões históricas até chegar à atualidade. Vislumbrou-se, ao final, que, não obstante serem adstritos ao sistema da civil law, possuem mecanismos distintos, mas com o mesmo objetivo, de evitar as decisões conflitantes e favorecer a uniformização das decisões judiciais.

Palavras-chave: Precedentes judiciais. Decisão judicial. Uniformização de jurisprudência. Assentos. Súmula vinculante.

\section{JUDICIAL PRECEDENTS AND THE LUSO-BRAZILIAN COMPARISON: SIMILARITY AND DISTINCTIONS}

\begin{abstract}
This paper aims to bring to the knowledge of society about the reality of the systems of judicial precedents in Brazil and Portugal, emphasizing the extent to which there are similarities or distinctions between such rules. We sought to use a deductive approach method, with a monographic procedure and indirect research techniques to examine the theme, going from historical issues to the present. In the end, it was seen that, despite being attached to the civil law system, they have different mechanisms, but with the same objective, to avoid conflicting decisions and favor the uniformity of judicial decisions.
\end{abstract}

Keywords: Court precedents. Judicial decision. Standardization of jurisprudence. Registrations. Binding precedent.

\section{INTRODUÇÃO}

A temática do presente artigo perpassa e se pauta a partir de uma análise dos precedentes obrigatórios, consoante as nuanças trazidas pelo jovem Código de Processo Civil (CPC) brasileiro. Trata-se de verificar se, a partir das principais normas que versam sobre o tema

\footnotetext{
${ }^{1}$ Mestre em Direito pela Universidade Federal da Paraíba (UFPB). Especialista em Direito Processual Civil pela Universidade UNIDERP-MS. Professor Substituto vinculado ao Departamento de Direito Privado do Curso de Ciências Jurídicas da Universidade Federal da Paraíba - Campus I - João Pessoa/PB. E-mail: franciscodiego.adv@gmail.com
} 
no processo brasileiro, perpassando-se, antes, por um breve histórico e conceitual da temática, pretendendo-se adentrar na realidade da uniformização de jurisprudência e dos antigos assentos da legislação processual portuguesa, comparando com a realidade brasileira para, ao final, dizer se há ou não semelhança e qual a situação em cada realidade em específico.

Neste feitio, o presente artigo tem como mote fazer um paralelo entre o sistema de precedentes adotados pelo CPC brasileiro e pelo CPC português, a partir da realidade dos precedentes no sistema brasileiro e do recurso para uniformização de jurisprudência ou extraordinário constante nas normas dos arts. 686 a 695 do CPC português.

Pretende-se fazer um estudo sobre o paralelo dos precedentes judiciais no Brasil e Portugal, bem como tecer breves comentários da realidade dos antigos assentos portugueses e as súmulas vinculantes brasileira como precedentes obrigatórios. Assim, o intuito é analisar a adoção dos precedentes judicias na tradição brasileira e da uniformização de jurisprudência e dos assentos em Portugal

Justifica-se a escolha do tema, tendo em vista que buscar-se-á elucidar e dirimir dúvidas acerca de uma temática extremamente interessante para os operadores do direito, especialmente por se buscar fazer um escorço histórico dos precedentes nos sistemas do common law e do civil law até chegar ao CPC brasileiro, mas, principalmente, entender as principais semelhanças e distinções desta realidade constante no sistema processual brasileiro em comparação com o CPC português, mesmo ambos sendo adstritos a realidade do civil law. Então, perscrutar e verificar se existe semelhança ou não em tal realidade luso-brasileira é fator justificante para o estudo da temática.

Como objetivo geral do presente estudo, pretende-se analisar o estudo dos precedentes judiciais à luz do ordenamento jurídico brasileiro e português. Especificadamente estudar-se-á desde o histórico dos precedentes até chegar à realidade do CPC brasileiro, perpassando-se pela ideia dos precedentes nos principais sistemas jurídicos conhecidos. Mas o foco é, em seguida, adentrar no principal mérito do estudo, qual seja, elencar as principais normas do CPC brasileiro que retratam a matéria dos precedentes judicias, a sua importância, o conceito, o motivo da sua existência e, além do mais, fazer um paralelo com a realidade do CPC português, desde os antigos assentos, que foram substituídos na legislação daquele país pelos arestos (acórdãos) e pelo recurso extraordinário, além de ver as principais considerações sobre o recurso e a ideia da uniformização da jurisprudência. 
Como problema da presente pesquisa, a pergunta que se pretende responder ao final é quais as semelhanças e distinções acerca dos precedentes judiciais à luz dos Códigos de Processo Civil luso-brasileiros e se se pode considerar que algum deles é mais avançado do que o outro e o que o eventualmente menos evoluído tem a aprender com o outro?

Nesse sentido, utilizou-se o método de abordagem dedutivo e o método de procedimento monográfico, com a vertente metodológica de abordagem qualitativa, comum no ramo jurídico, por se tratar da sociabilidade, do ser social, não se podendo enxergar o direito senão no contexto da sociedade. Por fim, quanto às técnicas de pesquisa, apontam-se a bibliográfica e a documental, de documentação indireta, a partir do auxílio de livros, doutrina, artigos na Internet, revistas etc.

O estudo se divide em cinco tópicos, contando com a introdução e as considerações finais, iniciando-se pelo conteúdo do histórico dos precedentes no direito processual.

Além disso, em seguida, traz-se uma reflexão acerca dos precedentes à luz do CPC brasileiro, perpassando-se, em seguida, a uma análise sobre os princípios umbilicalmente conectados a temática, além do retrato da súmula vinculante e, noutro tópico, elucidar-se-á sobre a aplicação dos precedentes no ordenamento jurídico português. Por último, dentro deste tópico, verificar-se-á a questão da adoção dos precedentes judicias na tradição brasileira e os assentos em Portugal, comparando com as súmulas vinculantes brasileiras e, ao fim e ao cabo, far-se-á alusão ao recurso de uniformização de jurisprudência constante nas normas dos art. 686 a 695 do CPC português.

Verifica-se como hipótese da presente pesquisa o pensamento de que em ambos os ordenamentos nos deparamos com o sistema da civil law e, ao mesmo tempo, quando se utiliza de instrumentos com o propósito dos precedentes judiciais das normas dos arts. 926 e 927 do CPC brasileiro e os 686 a 695 do CPC português, acerca do recurso de uniformização da jurisprudência, verifica-se que, no fundo, a ideia é de justamente almejar e encontrar um sistema mais harmônico, sem proferimento de decisões conflitantes, observando a igualdade, a segurança jurídica, a celeridade, com o expediente de um ativismo judicial e uma não obrigatoriedade de se ficar apenas adstrito a noção da legalidade. Ora, vislumbra-se que ambos os ordenamentos buscam atingir uma economia do direito com o intuito de eliminar processos que firam eventuais decisões paradigmáticas e já fixadas como precedentes judiciais pelos respectivos tribunais de cada país. Ou seja, apesar de nomenclaturas e caminhos distintos que possam existir entre as 
duas realidades, ao final, entende-se que as ideias são as mesmas: igualdade, segurança jurídica, celeridade e uniformização das decisões judiciais.

\section{CONCEITO E HISTÓRICO DOS PRECEDENTES JUDICIAIS E A INFLUÊNCIA DOS SISTEMAS LEGAIS CIVIL LAW E COMMON LAW}

No âmbito do direito processual civil, perpassando-se por todos os caminhos que um processo possui, seja na fase postulatória, probatória, decisória ou executiva, não se pode fechar os olhos para realidade de que o momento do proferimento das decisões judiciais de mérito pode ser taxado como sendo o ápice do processo. E, aqui, fala-se de qualquer decisão, seja a monocrática ou realizada por um colegiado. $\mathrm{O}$ fato é que o peso daquilo que for decidido pelo juízo será determinante para culminar para o desfecho do processo ${ }^{2}$.

Consoante noção cediça, Didier Jr., Braga e Oliveira (2016, p. 455) relata que o precedente é formado pelas circunstâncias de fato que fundamentam a polêmica, a tese ou o princípio jurídico firmado na exposição de motivos do julgamento favorável da decisão - a razão de decidir, além da argumentação jurídica no tocante à questão.

Tendo em vista isto, sabe-se que a ideia do precedente é a de uma decisão judicial que fora realizada em um determinado caso sub judice, em que tal elemento decisório e normativo terá condições de subsidiar julgados futuros, desde que, obviamente, trate-se de situações que envolvam questões semelhantes.

Macêdo (2014, p. 92-93) traz a lume a realidade de que o precedente, em sentido próprio, é uma fonte de direito que se refere a uma designação relacional entre duas decisões, enquanto, impropriamente, é norma que é exatamente a ratio decidendi. Esta razão de decidir, consoante Didier Jr., Braga e Oliveira (2016, p. 455-456), são os fundamentos jurídicos que subsidiam o veredito.

Ora, verifica-se, então, que o precedente se refere a uma norma elaborada por um órgão jurisdicional, em um caso individual, que pode se ajustar a finalidade para processos semelhantes no futuro. As razões de decidir do precedente procedem a vinculação e é a razão de decidir por indução, levando a que uma norma geral seja utilizada futuramente em outros julgados.

\footnotetext{
${ }^{2}$ Neste início, é interessante desde já destacar de que, segundo Didier Jr., Braga e Oliveira (2016, p. 457), a decisão judicial é o ato jurídico em que se advém a resolução da situação, visualizada no dispositivo do decisium, enquanto o precedente é referendado na fundamentação.
} 
Sobre isto, Mitidiero (2012) e Peixoto (2013) dispõem que o precedente é uma regra que é constituída por uma norma e que é utilizada por subsunção. Ele é, ao mesmo tempo, na visão deles, um fato que deve ser encarado como um ato-fato jurídico. Para Didier Jr., Braga e Oliveira (2016, p. 467), não obstante constante na fundamentação da decisão, pode-se o precedente ser visto como um fato, produzindo efeitos independentemente da vontade do juízo.

O estudo do sistema do common law deve ser realizado observando que ele proveio da Inglaterra, local originário dessa família jurídica que, em seguida, difundiu-se por países de língua inglesa. De acordo com Gilissen (2003, p. 210), devido a Carta Magna de 1215 e as provisões de Oxford, em 1258, houve a consubstanciação do estatuto de Wesminster II, em que o chanceler não podia criar direitos, mas utilizá-los em casos análogos. Souza (2011, p. 21), por sua vez, verifica que o common law veio à tona com sustentáculo no processo, mas não em regras sobre o pano do direito e, por isso, a sua base é o devido processo legal, e não a legalidade como ocorre nos países romano-germânicos.

No costume enraizado do sistema da common law, as características de fato e de direito relevantes e categóricas eram as vistas pelo julgamento no desfecho do caso em concreto, devendo estar habilitado para o julgamento do caso em outros casos específicos.

Observa-se, neste ínterim, que no common law o direito aparece diante de casos concretos e a respectiva apreciação dos juízes, que cria o precedente judiciário. Como aduz Zaneti Júnior (2016, p. 310-311), quando um Tribunal cria uma norma de direito indicado para certos fatos considerados importantes sob o viés jurídico, esta deverá ser aplicada e seguida nos futuros casos análogos. Mitchell (1936, p. 30) elucida, ainda, que o sobredito sistema se mostra como um direito jurisprudencial que, contudo, se equivale a um direito costumeiro, consagrado e perpetuado na jurisprudência.

O precedente judiciário, de modo isolado, não é tão considerado no costume arraigado do sistema da civil law. É mais importante a concessão realizada ao precedente judicial renovadamente produzido em decisões realizadas em casos futuros e que elabora, por conseguinte, a jurisprudência. É nesta continuidade e repetitividade homogênea e quantitativa do precedente e sua escolha interpretativa que gera uniformização e estabilidade à geral regra que 
dali é retirada, tornando-a pauta de comportamento e julgamento para quem julgado e para quem é julgado ${ }^{3}$.

Todavia, de acordo com Didier Jr., Braga e Oliveira (2016, p. 467), deve-se ter o cuidado e não é possível afirmar que apenas há precedentes nos países que adotam o common law, já que eles existem em todo o globo terrestre. O que se pode dizer, na visão do supracitado doutrinador, é que naqueles países lhes confere uma veneração com eficácia normativa.

Noutro norte, é sobremodo importante assinalar que o termo stare decisis ${ }^{4}$ advém da expressão latina stare decisis et non quieta movere, significando "manter a decisão". No common law ela pode ser encarada como espécie do gênero precedente, com vinculatividade horizontal dentro do mesmo tribunal, enquanto o precedente se refere a vinculatividade vertical entre os tribunais e os magistrados - juízos a quo. Todavia, para um entendimento mais admitido, vem-se encarando que o termo pode se referir tanato a um quanto ao outro (HENRIQUES FILHO, 2018, p. 396).

A cláusula do stare decisis, na visão de Manckiewicz (1954), significa se ater ao que fora decidido, observando a ideia de que toda decisão tende a se tornar uma decisão de diretrizes. Os membros podem discordar, a partir de uma opinião dissidente, mas prevalece a obrigação do stare decisis ${ }^{5}$.

A ordenação jurídico brasileira reconhece a elaboração e interpretação do direito pelo magistrado. A ação realizada por este é semelhante com a executada por um juiz pertencente ao sistema do common law, especialmente a empregada pelo magistrado norte-americano, tendo em vista que para ele é dado o dever-poder de realizar o controle de constitucionalidade das leis a um determinado caso em específico. Assim, pode-se verificar que a cultura judiciária dos precedentes judiciais se introduziu no âmbito do direito processual brasileiro.

Nesta toada, Versoza $(2017$, p. 79) traz à tona a realidade de que, por isso, a doutrina do stare decisis - leia-se, precedentes - tornou lugar comum, incorporando-se ao direito processual brasileiro.

\footnotetext{
${ }^{3}$ Consoante Mata-Machado (1953), o costume é visto como primazia no common law, seguido pela jurisprudência, a lei e a doutrina.

${ }^{4}$ Wambier (2010, p. 36) diz que a expressão almeja garantir as finalidades do precedente - previsibilidade, equidade, consistência e estabilidade, criando um sistema de normas.

${ }^{5}$ No direito norte-americano apenas se derruba o precedente obrigatório, na visão do supracitado doutrinador, pela ideia do overruling.
} 
Assim, vai-se percebendo que existe um posicionamento ultrapassado da dicotomia pertencente ao civil law e ao common law. Ora, se o primeiro fora conhecido como o que aplica a legalidade, não se pode questionar o fato de que há tempos ele vem se utilizando de outras fontes do direito para resolução dos conflitos, tais como a jurisprudência, os precedentes etc. Noutro norte, não se pode dizer mais que os países que adotam o common law não possuam codificações sobre questões jurídicas, e que apenas segue a ideia dos julgados em casos concretos. Não. Não merece prosperar tais narrativas, ante o fato de haver uma tendência de convergência entre tais sistemas - common law e civil law - no intuito de resolver de maneira eficiente os problemas práticos do sistema jurídico local.

Capelleti (1999, p. 123-124) trouxe à baila o movimento recíproco entre as duas famílias jurídicas, pois, não obstante reconhecer as diferenças entre os sistemas, atesta como verdadeiro que no civil law se encontra o surgimento do fenômeno conhecido pelo aumento da criatividade da jurisprudência.

Não é de hodiernamente que os exegetas do direito vêm procedendo ao estudo dos procedentes judiciais nos diversos sistemas jurídicos e no direito comparado. Advindos da realidade jurídica inglesa, mas hoje já encarados na teoria geral dos precedentes judiciais, é possível identificar conceitos como ratio decidendi, obter dictum, distinguishing e overrruling, que serão discutidos em momento oportuno neste artigo ${ }^{6}$.

A análise dos precedentes e da jurisprudência no Império e nos primeiros anos da república consistiam numa importante fonte de normas jurídicas, o que ia de encontro ao pensamento difundido pelo senso comum teórico. Isso porque, não obstante a influência romanogermânica, o Brasil também recebeu a influência do direito norte-americano (DIDIER JR.; SOUZA, 2015) ${ }^{7}$.

Constata-se, em consequência, que, nos primeiros anos da República brasileira se encontravam os precedentes, todavia, eles possuíam somente efeito persuasivo, sem obrigatória

\footnotetext{
${ }^{6}$ Para Didier Jr. e Souza (2015), parece haver um sendo comum de que a noção das recentes reformas do sistema jurídico processual com o intuito de fortalecer os precedentes judiciais no Brasil firmaram alterações no status quo que levaram a uma nova tradição, que valorizam a jurisprudência e os precedentes de modo mais intenso do que se imagina.

${ }^{7}$ Dolinger (1990, p. 803-837) faz alusão a diversas decisões proferidas pela Suprema Corte norte-americana que serviram de fundamento para elaboração de diversos precedentes do tribunal brasileiro com expressa referência ao direito constitucional estadunidense. A norma do art. 386 do Decreto no 848/1890 também ressaltou que "os estatutos dos povos cultos e especialmente os que regem as relações jurídicas na República dos Estados Unidos da América do Norte, os casos de common law e equity, serão também subsidiários da jurisprudência e processo federal" (BRASIL, 1890).
} 
vinculatividade. Com o decorrer dos tempos se foi demonstrando a relevância da divulgação da cópia dos julgados, tendo em vista que por meio delas se pode alcançar o entendimento da sua importância enquanto paradigma a ser aplicado noutro julgado. Tanto é que houve a elaboração de um sistema de decisões do Supremo Tribunal Federal (STF), além de ter sido estabelecida uma disciplina em todos os regimentos internos do STF desde 1891, constando todos os precedentes autorizados nos repositórios do tribunal e a respectiva publicação oficial delas nos diários oficiais da República. (DIDIER JR.; SOUZA, 2015).

É possível afirmar que muitas das características e instrumentos pertinentes aos precedentes do direito republicando vieram do direito luso-brasileiro mediante, por exemplo, a ausência de vinculatividade dos precedentes e o uso de manifestações abstratas para estabelecer a jurisprudência. E, não obstante os assentos - pertencentes ao direito processual português hajam sido revogados, regressaram com outras nomenclaturas, com o intuito de proceder a tradição dos pronunciamentos abstratos dos tribunais superiores com o objetivo de elaborar a jurisprudência, a estabilidade e favorecer a não existência de precedentes contraditórios.

No Brasil, após a Segunda Grande Guerra se enxerga o surgimento de um póspositivismo, em que há uma superação da ideia de aplicação fria da lei, de que o legislativo dita o que será reproduzido pelos magistrados, alterando para possibilidade de aplicação discricionária da norma pelo julgado. Não se pode quedar inerte, então, que a aplicação dos precedentes é essencial para guarida dos princípios da segurança jurídica, da justificação das decisões judiciais, uniformizando a aplicação do direito e contribuindo para a celeridade e eficiência do sistema judicial (NUNES; LACERDA; MIRANDA, 2013).

Nesta toada, verifica que se deve ter cuidado e atenção ao querer dizer que o sistema do common law não é adotado no âmbito do direito brasileiro. Em absoluto, sabe-se que o Brasil se acosta ao civil law, mas possui ligação, junto ao direito inglês e estadunidense, a existência de uma realidade que observa os precedentes do sistema anglo-saxônico.

Verdade seja, Henriques Filho (2018, p. 108) chama a atenção de que, no Brasil, há um problema escancarado da divergência jurisprudencial. Há, na visão de Wambier (2009), várias pautas de condutas distintas e não compatíveis para os jurisdicionados.

Tal tema passará a ser debatido com mais ênfase no próximo tópico, a qual se remete o leitor. 


\section{PRECEDENTES DE ACORDO COM O CPC BRASILEIRO}

O Poder Judiciário brasileiro é normatizado a partir dos arts. 92 ao 126 da Constituição da República Federativa do Brasil de 1988 (CRFB/1988). Com o intuito de proceder a função jurisdicional, atipicamente ele atua administrativa e legislativamente, vinculando a organização interna dos tribunais. Com a Emenda Constitucional $n^{\circ}$ 45/2004 passou a vir à tona, dentre outras, a ideia de celeridade processual e se criou o instrumento da súmula vinculante. Verificase, nesta toada, que houve uma maior independência a este Poder, com a autonomia das suas decisões (HENRIQUES FILHO, 2018, p. 142-143).

Antes do CPC brasileiro verificava-se a existência do reconhecimento dos precedentes como uma fonte secundária em que a prática judicial lhes concedia argumentos de reforços relevantes, mas não vinculantes no que tange às decisões dos casos-pilotos. Devido ao princípio de preservação da liberdade de convencimento e decisão do juízo, observa-se que as divergências são reconhecidas como um efeito colateral advindo da tradição do civil law (BRASIL; LELIS, 2016).

Não obstante isso, impende observar que existe doutrina, como a de Streck e Abboud (2013, p. 52-56), que afirma pela inexistência do regime de precedentes no ordenamento jurídico brasileiro, pois não o vislumbram com a ideia do regime de súmulas. Eles trazem à lume a realidade de que, no Brasil, o magistrado busca descobrir o sentido normativo para aplicar o direito. Contra eles, Didier Jr., Braga e Oliveira (2016) e Souza (2011), para quem os precedentes servem como diretriz para julgamento de casos futuro e análogos, sendo instrumento promotor ao ordenamento jurídico brasileiro. Esta última é a que prevalece.

Sobre a discussão, Versoza (2017, p. 81-82) entende que o regime de precedente judicial se desenvolve metodologicamente e juridicamente de maneira destoante ao mecanismo sumular com o intuito de observar a constituição de critérios jurídico-jurisprudenciais no Brasil, razão pela qual se acosta ao entendimento de Streck e Abboud (2013) ${ }^{8}$, não vislumbrando que os instrumentos previstos de padronização e vinculação da jurisprudência não elaboram normatividade jurídica-jurisprudencial em seu sentido próprio.

Todavia, apesar dos relatos dos parágrafos anteriores, constata-se que o jovem CPC brasileiro tem como mote, na norma do art. 926, o intuito de uniformizar a jurisprudência e

\footnotetext{
${ }^{8}$ Para Streck e Abboud (2013), as súmulas vinculantes não são precedentes judiciais, já que o precedente não aufere força mediante simples imposição do legislador, tal como ocorre com a súmula.
} 
conservá-la de maneira estável, íntegra e coerente. Devido a isto, Didier Jr. e Cunha (2016, p. 605) relata que os magistrados e os tribunais devem fixar os olhos com atenção nos acórdãos em incidente de assunção de competência, do Incidente da Resolução de Demandas Repetitivas (IRDR) e em julgamentos repetitivos de Recurso Especial (REsp) e Recurso Extraordinário $(\mathrm{RE})^{9}$. O supracitado doutrinador alude, ainda, que diante do surgimento dos precedentes obrigatórios, juízos e tribunais devem cumprir a regra de segui-los, seja ao proferir julgamento de improcedência liminar, ou dispensando remessa necessária, ou autorizando a concessão de tutela provisória de evidência ou, por fim, conferindo poder ao relator de um recurso em decidilo monocraticamente.

No tocante a assunção de competência e ao IRDR, é sobremodo importante assinalar que são uma forma concentrada de precedentes obrigatórios, procedendo-se a realização de audiências públicas, com a admissibilidade de participação de amicus curiae e com a observância do contraditório amplo. Chama-se a atenção do rol do $\S 1^{\text {o }}$ do art. 489 do CPC brasileiro $^{10}$, pois para se formar o precedente e aplicá-lo passar-se-á pela similitude ou distinção do caso em concreto.

No Brasil existem precedentes com força vinculante enumerados na norma do art. 927 do CPC brasileiro. Devem os juízes reconhecê-los ex offcio, sob o perigo de ser encarado como omisso ou denegatório da justiça. Além disso, merece ser salientado que embora o rol não seja taxativo, as súmulas, por exemplo, de cada um dos tribunais possuem força obrigatória no tocante ao próprio tribunal e magistrados que estejam adstritos a ele (DIDIER JR.; BRAGA; OLIVEIRA, 2016, p. 469, 474).

Além do mais, impende salientar que cabe uma ação - denominada de reclamação - em desfavor daqueles que se sentirem prejudicados pela não observância de uma decisão proferida em julgamento de casos repetitivos ou de assunção de competência, podendo tal decisão ser

\footnotetext{
${ }^{9}$ Didier Jr. e Cunha (2016, p. 605) chama a atenção para a realidade que a assunção de competência, o IRDR e os recursos repetitivos são uma constituição concentrada de precedentes obrigatórios.

10 "\$ $1^{\circ}$ Não se considera fundamentada qualquer decisão judicial, seja ela interlocutória, sentença ou acórdão, que: I - se limitar à indicação, à reprodução ou à paráfrase de ato normativo, sem explicar sua relação com a causa ou a questão decidida; II - empregar conceitos jurídicos indeterminados, sem explicar o motivo concreto de sua incidência no caso; III - invocar motivos que se prestariam a justificar qualquer outra decisão; IV não enfrentar todos os argumentos deduzidos no processo capazes de, em tese, infirmar a conclusão adotada pelo julgador; V - se limitar a invocar precedente ou enunciado de súmula, sem identificar seus fundamentos determinantes nem demonstrar que o caso sob julgamento se ajusta àqueles fundamentos; VI - deixar de seguir enunciado de súmula, jurisprudência ou precedente invocado pela parte, sem demonstrar a existência de distinção no caso em julgamento ou a superação do entendimento." (BRASIL, 2015).
} 
taxada de omissa por justamente silenciar acerca dos julgados paradigmáticos - precedentes judiciais obrigatórios.

Existe, na visão de Didier Jr. e Cunha (2016, p. 605-607), um microssistema de formação concentrada de precedentes obrigatórios, em que há uma qualificação na discussão, com uma fundamentação mais forte e uma extensa publicidade, além de tornar mais abrangente a cognição para a formação concentrada dos precedentes. O citado doutrinador ainda chama a atenção para realidade de que com o incidente de inconstitucionalidade, o IRDR e o incidente em recurso repetitivo ocasionam, além da solução do caso sub judice - a quem chama de caso piloto, uma deliberação abstrata da questão de direito discutida e debatida no âmbito do tribunal ${ }^{11}$.

Existe a tese e o caso-piloto. A primeira é o incidente em que as partes se deparam com a suspensão dos processos na espera da resolução do julgado chave, enquanto no julgamento concreto as parte são assistentes simples de uma das demandantes do caso-piloto, já que participam, em nome próprio, na proteção de direito alheio (DIDIER JR.; CUNHA, 2016, p. $608)^{12}$.

Não se pode fechar os olhos para a realidade da ampla participação de interessados, tais como o amicus curiae, com o intuito de solucionar a tese sobrestada, razão pela qual para elaboração do precedente se deve ampliar a cognição e haver uma discussão qualificada. Há a participação obrigatória do Ministério Público, em situações as quais ele não seja o requerente, afinal de contas, haverá a criação de uma norma jurídica de origem jurisdicional.

Noutro norte, conforme explicitado por Didier Jr., Braga e Oliveira (2016, p. 487), o dever de uniformizar perpassa a ideia de que o tribunal não pode ser omisso ante uma divergência dentro do seu recinto, seja pelos órgãos fracionários ou especiais, acerca da mesma matéria de direito. O tribunal deve solucionar tal distinção, uniformizando o entendimento do conteúdo jurídico.

Além do mais, qualquer superação ou overruling merece ser fundamentada de maneira pertinente, assim como pode haver a modulação da eficácia em respeito a segurança jurídica.

Um precedente, quando reiteradamente é aplicado se torna uma jurisprudência, que, ao dominar o tribunal poderá ensejar à edição de uma súmula da jurisprudência do tribunal. Neste

11 É interessante enxergar ainda que tal decisão atingirá todos os casos que envolvam a mesma questão jurídica, fixando uma ratio decidendi a ser devidamente seguida.

12 Temer (2015, p. 135) diz que se trata de causa-modelo, e não causa-piloto, tendo em vista que o tribunal só fixa uma tese, mas não julga o caso, não havendo que se referendar uma suposta assistência das partes dos processos sobrestados. 
feitio, de acordo com Didier Jr., Braga e Oliveira (2016, p. 500), súmula é o enunciado normativo da norma geral de uma jurisprudência que é predominante.

Taruffo (2011, p. 142-143) chama a atenção para a distinção existente entre os termos precedente e jurisprudência, pois o primeiro, via de regra, referencia-se a uma decisão a um caso particular, enquanto o segundo se acosta a uma pluralidade de decisões, com maior amplitude de vários casos concretos ${ }^{13}$.

Versoza (2017, p. 86) aduz que a súmula pode ser encarada como meio que ocorre por meio do modelo da subsunção, encarada como dado objetivo-normativo, que constitui para ser uma fórmula de adesão a decisões anteriores, em que a aplicação se concretiza de forma automática, sem considerar a fundamentação responsável pela legítima elaboração do precedente judicial.

Para Henriques Filho (2018, p. 263), apesar da jurisprudência ter o intuito de criar normas ou exigir a vinculação das decisões, enxerga-se ser possível, mediante ela, garantir a mínima estabilidade jurídica às decisões.

O distinguishing é uma metodologia de confronto, que tem como mote conferir se o caso em julgado pode ou não ser taxado de semelhante ao paradigmático. Ele é um reflexo do princípio da igualdade e, nele, o juízo deverá julgar a partir da distinção, que propõe a aplicação de qualquer precedente, mesmo os vinculantes.

A ideia da supracitada teoria é tão importante porque retira o pensamento de que um determinado precedente será aplicado de forma automática, sem qualquer análise. Não é assim. Da mesma forma como o juízo precisa interpretar a lei e observar se os fatos concretos estão umbilicalmente ligados a hipótese normativa, convém também analisar o precedente para ver a sua adequabilidade para a situação concreta à sua ratio decidendi.

Além do mais, existe o overruling, que nada mais é do que uma outra técnica de confronto, interpretação e aplicação dos precedentes, com o intuito de superar um precedente prévio. Ora, aqui, um precedente vinculante perde sua força e é substituído por outro. O próprio tribunal procederá a alteração, que pode ser expressa ou implícita. Todavia, esta última forma não é admissível no Brasil, que exige a fundamentação específica para substituição, consoante $\S$ $4^{\circ}$ da norma do art. 927 do CPC brasileiro.

\footnotetext{
${ }^{13}$ A jurisprudência, consoante Venosa (2003) é como um conjunto de decisões, com o trabalho diuturno dos tribunais. É o próprio direito vivo, preenchendo lacunas nos casos concretos.
} 
Noutro norte, impende salientar alguns princípios acerca da temática central deste artigo, qual seja, os precedentes. Primeiro, faz-se alusão ao princípio da legalidade, que expõe que o magistrado decida as questões de acordo com o direito. É o dever de integridade do art. 926 do CPC brasileiro. Diz-se isso, pois, que não há direito apenas na lei, bem como este não existe apenas se for escrito ou proveniente de um processo legislativo estatal. Assim, vislumbrase que o cumprimento dos precedentes judiciais e da jurisprudência dos tribunais contribui para ressignificação do sobredito princípio, pois eles compõem o direito.

Além desse, o princípio da igualdade merece ser remodelado, pois, consoante Didier Jr., Braga e Oliveira (2016, p. 481), deve ser encarado como igualdade no tocante ao direito, mas não somente a lei, e sim sobre a norma jurídica ${ }^{14}$. Ele ainda destaca que com o intuito de evitar o surgimento de decisões conflitantes no âmbito de determinado tribunal é que surge a ideia da uniformização da jurisprudência, acostada a nuança da estabilidade, integridade e coerência da norma do 926 do CPC brasileiro.

Além do mais, é pertinente fazer alusão ao princípio da segurança jurídica, sob a ideia de que quaisquer atos normativos do Estado serão atingidos por situações que foram consolidadas no passado. Para Didier Jr., Braga e Oliveira (2016, p. 483), tal princípio precisa ser revisto, pois não tutela situações consolidadas no passado como também legitima o que surgirá e os comportamentos do presente. E continua aduzindo que o mencionado princípio está umbilicalmente ligado a proteção da confiança, repercutindo no direito processual ao garantir deveres de uniformização jurisprudencial com manutenção da estabilidade, integridade e coerência.

A observância do art. $489, \S 1^{\circ}$, e do $927, \S 1^{\circ}$, precisam ser vistas para uma remodelação do entendimento do princípio da motivação das decisões judiciais, com fulcro no art. 93, IX, da CRFB/1988. Deve-se verificar e considerar a função extraprocessual da fundamentação, ao visualizar que ela não pretende somente justificar a ideia defendida por determinado juízo. Em um mundo em que se busca encarar o processo cada vez mais sob os auspícios dos precedentes judiciais, que poderá ser invocado, inclusive, por pessoas que não participaram do processo em específico.

Por isso, Didier Jr., Braga e Oliveira (2016, p. 484) trazem à baila que as decisões judiciais precisam ser motivadas de modo mais firme, observando como adequado não apenas o

${ }^{14}$ Para Marinoni (2010, p. 228-233), não há que haver a igualdade apenas no acesso à justiça, ou exercício da função jurisdicional, paridade de armas, mas também sob a perspectiva da igualdade perante as decisões judiciais. 
que fora dito pelo juízo, como também o que foi considerado útil para fundamentação da solução do caso e a magistral identificação do precedente.

Além do mais, é necessário ressaltar a existência das súmulas vinculantes. Tal regime se encontra explicitado na norma do art. 103-A da CRFB/88 e na Lei ${ }^{\circ}$ 11.417/2006. Ela tem como característica principal ter efeito vinculante em relação ao próprio STF, bem como aos demais órgãos do Poder Judiciário brasileiro e aos órgãos da administração pública direta e indireta. $\mathrm{O}$ STF, inclusive, poderá modular os efeitos da decisão, para que os seus efeitos se fixem em data futura, por exemplo.

Admite-se a edição de súmula vinculante a partir da interpretação ou verificação ou eficácia de normas determinadas, em que haja controvérsia entre órgãos do Poder Judiciário, ou entre esses e administração pública, ocasionando insegurança jurídica grave e um exacerbado número de processos sobre questão idêntica. A matéria tem que ser constitucional e a competência, obviamente, é do STF, que poderá revisar ou cancelar tais enunciados.

A diferença fundamental entre precedente e súmula, independentemente se vinculante ou não, perpassa pela realidade de que as súmulas no direito brasileiro foram concebidas como um recurso rápido de casos repetitivos, sem a garantia da segurança jurídica ou estabilidade. Apesar disso, as súmulas são taxadas de mero enunciado geral e abstrato, sem ser possível visualizar a ratio decidendi e os fatos que ensejou a formação. Assim, sua aplicação de modo correto pode ser prejudicada.

Para Henriques Filho (2018, p. 448), o efeito vinculante apenas em proposição abstrata, mas não na razão de decidir, não pode mensurar quais os casos realmente análogos ao casopiloto que ocasionou o surgimento da súmula, dando prejuízo a aplicação, tendo em vista que se torna possível apenas uma aplicação destituída da razão uniformizante a situações que não são pontualmente iguais a súmula. Do mesmo modo, não manifestada a razão de decidir, nem possuindo o viés vinculante, prejudica-se o distinguishing e, por conseguinte, não há um debate jurídico rico, tratando-se, da mesma maneira, de casos distintos.

De acordo, ainda com Henriques Filho (2018, p. 450-451), a súmula se distingue dos precedentes, pois estes buscam a unidade da ordem jurídica, consoante a segurança e a igualdade, visando o futuro, enquanto a súmula é um enunciado geral e abstrato traçado para casos que estão por vir, esquecendo-se o caso concreto que deu origem a ela. Demais, as súmulas não possuem possibilidade de estender ou extinguir, ou seja, não pode sofrer distinguishing, 
tendo em vista que não é possível proceder quais os valores que a estabeleceram. Ou seja, são vistas como ferramentas autônomas em relação aos fatos e valores dos precedentes que as inspirou.

Portanto, verifica-se que existem diversos instrumentos ou mecanismos que podem ser utilizados no âmbito do CPC brasileiro em prol da uniformização da jurisprudência e das decisões judiciais, evitando-se a insegurança jurídica - ao menos, teoricamente, por mais utópico que possa parecer - e contribuindo para a celeridade, segurança jurídica e igualdade entre as partes.

\section{PRECEDENTES NO ORDENAMENTO JURÍDICO PORTUGUÊS}

Assim como ocorreu com o Brasil, o estudo do Poder Judiciário português sofreu profundas mutações pela civil law. Nele se encontra o tribunal constitucional ${ }^{15}$, que funciona isoladamente do Supremo Tribunal de Justiça, que é o órgão superior da hierarquia dos tribunais em Portugal (só reconhece matéria de direito), que tem, como uma das suas competências proceder a uniformização da jurisprudência. Além deles há os Tribunais de Relação, que são cinco.

Deste modo, verifica-se que a estrutura judiciária em Portugal é dividida em um Supremo Tribunal de Justiça, com seções cíveis, criminais e do trabalho, cinco Tribunais de Relação - $2^{\mathrm{a}}$ instância -, também com seções cíveis, criminais e do trabalho e dezoito Tribunais de comarca $-1^{\mathrm{a}}$ instância, com divisão em competência genérica ou especializada.

A justiça portuguesa, a nível recursal, roga por observância de determinados critérios pecuniários do valor da causa como requisitos para admissibilidade recursal. Mas existem algumas exceções como, por exemplo, em determinados casos, não obstante o valor processual ser superior a trinta mil euros, a lei não admite recurso para o Supremo Tribunal de Justiça. Todavia, admite-se, excepcionalmente, a interposição de recurso para o Supremo quando a decisão impugnada da Relação se encontre em dissidência de outro acórdão da Relação, com o intuito de proceder a resolução da contradição jurisprudencial, independentemente do valor da alçada (GERALDES, 2017).

15 Conforme o art. 221 da Constituição da República Portuguesa, ele é competente para administrar a justiça em matérias jurídico-constitucionais, assim como analisar a inconstitucionalidade e ilegalidade das normas. (PORTUGAL, 1973). 
Outro exemplo que independe do valor para interposição são as decisões ou acórdãos que não tenham respeitado a jurisprudência uniformizadora do Supremo Tribunal de Justiça, consoante a norma do art. 629 do CPC português. Por fim, ainda, cita o Ministro da Corte Superior portuguesa que existindo a situação de dupla conformidade ${ }^{16}$ poderá dar ensejo a interposição de um recurso de revista excepcional que, para ser admissível, precisa preencher determinados requisitos, dentre eles, a existência de contradição entre o acórdão da Relação que é objeto do recurso e outro acórdão da relação ou do Supremo acerca da mesma temática do direito (GERALDES, 2017).

De acordo com Geraldes (2017), com fins de uniformização de jurisprudência, o julgamento será ampliado pelo Pleno das Seções Cíveis, consoante arts. 686 e 687 do CPC português. A jurisprudência uniformizada do Supremo Tribunal de Justiça poderá se realizar quando existir julgamento ampliado do Recurso de Revista e o Presidente do Supremo entenda como indispensável ou conveniente a uniformização. Para isso observar-se-á a existência de contrariedade com alguma anterior jurisprudência uniformizada, almejando evidenciar determinada interpretação de normas ${ }^{17}$. Além do mais, é admissível Recurso Extraordinário para uniformização de jurisprudência, desde que observados determinados requisitos legais ${ }^{18}$. O julgamento ocorre no pleno das Seções Cíveis (GERALDES, 2017).

Verdade seja, para Geraldes (2017) a importância da jurisprudência uniformizada do Supremo Tribunal de Justiça perpassa pela realidade de que a jurisprudência não é fonte formal de direito; que ela não possui força vinculativa, quer seja interna ou externa; possui valor persuasivo e exerce uma força persuasiva forte, tendo em vista que se os Tribunais inferiores não seguirem a jurisprudência uniformizada, as decisões proferidas admitem sempre recurso até o Supremo independentemente do valor da causa. Tais fatores têm corroborado para os tribunais de $1^{\mathrm{a}}$ instância e os da Relação observarem a jurisprudência uniformizada.

Geraldes (2015) expõe que no sistema português, como em grande parte dos europeus, o Supremo não possui a função eminente de tribunal de cassação que almeja sindicar a matéria de

${ }^{16}$ Ocorre quando o acórdão do Tribunal da Relação tenha confirmado a decisão da $1^{\text {a }}$ instância; não haja voto de vencido; e tenha sido utilizada em ambas as decisões a mesma fundamentação.

17 Observa-se, ainda, o quórum mínimo de 3/4 dos juízes das seções cíveis e o acórdão final é publicado no Diário da República para divulgação.

18 “Trânsito em julgado do acórdão do Supremo; verificação de contradição entre o acórdão do Supremo e outro acórdão do Supremo Tribunal relativamente à mesma questão essencial de direito; os acórdãos em confronto devem ter sido proferidos no domínio da mesma legislação; o recurso não é admissível se o acórdão recorrido estiver de acordo com um anterior acórdão de uniformização de jurisprudência; o recurso deve ser apresentado no prazo de 30 dias após o trânsito em julgado.” (GERALDES, 2017, p. 5). 
direito, permitindo que as instâncias a quo apliquem ao caso concreto. Ora, ao contrário, o Supremo desempenha como mote substituir situações que atinjam direta e imediatamente casos concretos e o resultado da sua função essencial no campo jurídico, consoante arts. 682 a 684 do CPC português ${ }^{19}$.

Ao contrário dos assentos, como ocorria com o código de 1966, os acórdãos de uniformização não possuem força vinculativa, ressalvando-se no âmbito de processo em que são proferidos. Mas há de se admitir que o Supremo vem atuando com força persuasiva em tais decisões, com base, especialmente, na fundamentação ${ }^{20}$.

Para Versoza (2017, p. 45), a decisão judicial estabelecida no recurso extraordinário firma uma estabilização da jurisprudência com o intuito de solucionar o conflito de interpretação, com incidência sob todos os tribunais submetidos que proferiu aquela decisão.

Além do mais, impende verificar que a Casa de Suplicação era o tribunal superior ordinário da justiça portuguesa mais importante. Apenas o Rei ou o Desembargo do Paço poderiam reconsiderar as sentenças. Os precedentes elaborados por ela devem se referenciar por seus arestos e assentos, que são decisões abstratas que serviam à uniformização da jurisprudência e a instituição de uma interpretação genuína da lei pelo tribunal (SOUZA, 2017, p. 3).

Souza (2017, p.1) destaca que diferentemente do pensamento comum de que a ausência de vinculatividade dos precedentes judiciais no Brasil não está fundada nas questões históricas e da tradição romano-germânica. Naquela época, elucida o autor, à expressão aresto era utilizada para nomear as decisões judiciais que eram qualificadas como precedentes para casos análogos futuramente colocados a discussão.

Os assentos são julgados em colegiado acerca da interpretação autêntica de uma específica norma legal por um tribunal competente, sendo reputados como indispensáveis para uniformização da interpretação diante precedentes divergentes nos tribunais.

A maior discussão, na visão de Souza $(2017$, p. 3) da época era admitir a ligação ou não dos magistrados aos precedentes da casa de Suplicação. Tucci (2004, p. 83-89), processualista da vanguarda, suscita a distinção literal do sistema romano-germânico com o fragmento do Digesto que admitia os enunciados de estatutos, costumes ou autoridade de decisões como força de lei.

${ }^{19}$ A uniformização de jurisprudência pode ser taxada como um expoente máximo da atividade judiciária de um tribunal de revista.

${ }^{20}$ Em 2007, de acordo com Geraldes (2015), houve a reintrodução do recurso extraordinário para o Pleno, objetivando a uniformização da jurisprudência e, agora, junto com o julgamento da revista formam a dupla possibilidade de alcançar o Supremo visando a uniformização. 
A força de lei pode ser vista, de acordo com Souza (2017, p. 4-5) com a vinculatividade do precedente judicial. Tinha uma antevisão nas Ordenações de precedente com efeito vinculante, que resultavam de decisão proferida pelo Rei em decisão de integração de lacuna, associada a eficácia em face de todos os casos semelhantes.

Consoante Geraldes (2015), a abolição da figura dos assentos ocorreu em 1995, mas tal atitude não desprezou a função de uniformização, que continuou a ocorrer com o julgamento ampliado da revista e do agravo em $2^{\mathrm{a}}$ instância, como consagrado no CPC de 1961. Era não somente para sanar eventuais contradições jurisprudenciais, mas para impedir a consumação das contradições, prejudicando a segurança jurídica e a igualdade entre as partes.

Versoza (2017, p. 88-89) faz uma comparação entre os assentos portugueses e as súmulas vinculantes no Brasil. Para ela, a jurisprudência é um estabilizador do qual decorre a experimentação da solução de um problema vivenciado na história jurídico-social e, aduz que tais institutos, não obstante serem oriundos do Poder Judiciário, são como não jurisprudenciais, revelando o sentido dogmático de leis, ao serem medidas estabilizadoras de expectativas congruentes com valor normativo que veio da autoridade político-jurídica.

Os dois institutos acima podem ser vistos como manifestação prévia de solução jurídica com alcance geral, que apoiam resolução de imbróglios jurídicos do futuro, estabelecendo a interpretação correta e atingindo a uniformidade jurisprudencial.

Demais e ainda, conforme Versoza (2017), deve-se destacar que os assentos e a súmula vinculante almejaram alcançar o direito concebido de maneira de projeto normativo em prol da uniformidade jurisprudencial, ou seja, uma espécie de total organização a partir de normas gerais-abstratas. E, por conseguinte, esses institutos preparam um direito judicial reconhecido com a normatividade geral-abstrata e percebidas pelo Tribunal Superior com o intuito de conceder unidade interpretativa da lei.

Os antigos assentos ou os atuais precedentes brasileiros não devem ficar adstritos ao princípio da igualdade enquanto sobram desamparados destes instrumentos de atualização dos institutos uniformizadores. Elaborar regra geral mediante julgado, na visão de Neves (1983) é um atrevimento que somente poderia ser compensado a um procedimento célere e eficaz de flexibilização das tais normas judiciais vinculantes.

Consoante Henriques Filho (2018, p. 516-517), existia um ponto de encontro entre os precedentes brasileiros e assentos portugueses, já que estes significam um enunciado prescritivo 
formal fixo, com premissas uniformes e abstratamente determinadas, diferentemente dos precedentes, pois que com eles há diferença material e uma certa flexibilização normativa, com possibilidades de adaptações necessárias quando forem requeridas. No Brasil é muito mais criativa e expansiva do que no berço da origem do common law, pois há uma inclinação da continuidade de uma cultura mais amena da produção legislativa em assuntos que intencionalmente o legislador comum deixou a cargo das cortes, a nível de controle jurisdicional.

Neste feitio, a experiência portuguesa demonstra diversas e necessárias adequações ao chamado precedente brasileiro para que seja utilizado de guia decisório, sem adentrar no território do legislador e, menos ainda, ser um obstáculo para a construção de um direito mais justo pelas mãos dos julgadores nacionais.

\section{CONSIDERAÇÕES FINAIS}

Em face das explanações levadas a cabo no presente artigo, conclui-se tratar de um tema polêmico, trazendo à baila de que tanto no direito processual civil brasileiro, como no português, .se encontram instrumentos que trazem a ideia dos precedentes idealizados no sistema da common law, apesar de os dois países adotarem, em sua essência, a sistemática da preponderância da lei - civil law.

Sejam os precedentes judiciais constantes no CPC brasileiro, como com o IRDR, os recursos especiais ou extraordinários repetitivos, as súmulas - vinculantes ou não, dentre outros; ou, então, os antigos assentos, o recurso de uniformização de jurisprudência ou recurso extraordinário admitidos na legislação processual portuguesa, em ambos os vieses, há o intuito de se buscar alcançar um sistema harmônico, sem decisões conflitantes a partir da elaboração de uma decisão paradigmática, em que todos deverão observar, via de regra, em casos semelhantes análogos, respeitando, além do mais, a igualdade, a celeridade e a uniformização das decisões judiciais.

Demonstra-se, então, a importância de se estudar a temática, pois a segurança jurídica é um norte basilar do direito processual. A ideia de ficar restrito ao teor normativo da lei, que há muito tempo se dizia como a única forma de dizer o direito nos países romano-germânicos, o que, vimos, não merece prosperar, já que hodiernamente o que existe é um sincretismo em prol 
de se alcançar o ideal de justiça, assim como a eficiência processual. Pois bem, a realidade do ativismo judicial demonstra ser uma forte aliada na elaboração dos precedentes judiciais.

Portanto, verifica-se que tanto no Brasil, como em Portugal, se busca atingir a realidade de uma economia do direito, visando eliminar processos futuros que possuam a mesma realidade fático-jurídica da decisão já escolhida como causa-piloto para firmar um precedente judicial pelos respectivos tribunais, leia-se, julgador em cada país. Assim, com nomenclaturas, instrumentos e caminhos distintos, ao final, percebe-se que o objetivo luso-brasileiro é idêntico, possuindo mais semelhanças do que diferenças.

\section{REFERÊNCIAS}

BRASIL. Constituição (1988). Constituição da República Federativa do Brasil. Diário Oficial [da] República Federativa do Brasil, Brasília, DF, 5 out. 1988.

BRASIL. Decreto n $^{\circ} 848$, de 11 de outubro de 1890. Organiza a Justiça Federal. Coleção de Leis do Brasil, Rio de Janeiro, 1890.

BRASIL. Lei no 13.105, de 16 de março de 2015. Código de Processo Civil. Diário Oficial [da] República Federativa do Brasil, Brasília, DF, 17 mar. 2015.

BRASIL, Deilton Ribeiro; LELIS, Henrique Rodrigues. A aproximação dos sistemas jurídicos do common law e civil law: os precedentes judiciais no Código de Processo Civil. In: ENCONTRO INTERNACIONAL DO CONPEDI, 7., 2017, Braga, Portugal. Anais [...] Florianópolis: Conpedi, 2017. p. 149-173.

CAPPELLETI, Mauro. Juízes legisladores? Porto Alegre: Sergio Antonio Fabris Editor, 1999.

CRETELLA JUNIOR, José. Direito romano moderno. 4. ed. Rio de Janeiro: Forense, 1986.

DAVID, René. Os grandes sistemas do direito contemporâneo. Tradução de Hermínio A. Carvalho. 3. ed. São Paulo: Martins Fontes, 1996.

DIDIER JR., Freddie; SOUZA, Marcus Seixas. O respeito aos precedentes como diretriz histórica do direito brasileiro. Revista de Processo Comparado, v. 2, p. 99-120, 2015.

DIDIER JR., Fredie; BRAGA, Paul Sarno; OLIVEIRA, Rafael Alexandria. Curso de direito processual civil: teoria da prova, direito probatório, ações probatórias, decisão, precedente, coisa julgada e antecipação dos efeitos da tutela. 11. ed. Salvador: Juspodivm, 2016. v. 2.

DIDIER JR., Fredie; CUNHA, Leonardo Carneiro da. Curso de processo civil. 13. ed. Salvador: Juspodivm, 2016. v. 3. 
DOLINGER, Jacob. The influence of American constitutional law on the Brazilian legal system.

The American Journal of Comparative Law, v. 38, n. 4, p. 803-837, 1990.

GERALDES, António Santos Abrantes. Uniformização de jurisprudência. Lisboa: STJ, 25 jun. 2015. Disponível em: https://www.fd.unl.pt/docentes_docs/ma/ager_MA_26301.pdf. Acesso em: 2 maio 2020.

GERALDES, António Santos Abrantes. Papel do Supremo Tribunal de Justiça na orientação da jurisprudência: procedimentos de uniformização: breves notas. Lisboa: STJ, abr. 2017. Disponível em: https://www.stj.pt/wp-content/uploads/2017/04/abrantes_geraldes. pdf. Acesso em: 2 maio 2020.

GILISSEN, John. Introdução histórica do direito. Tradução de A. M. Hespanha e L. M. Macaísta Malheiros. 4. ed. Lisboa: Fundação Calouste Gulbenkian, 2003.

HENRIQUES FILHO, Ruy Alves. Diálogo de tradições e a formação dos precedentes judiciais qualificados na civil law. $620 \mathrm{f}$. Tese (Doutorado em Ciências Jurídico-Políticas) Faculdade de Direito da Universidade de Lisboa, Lisboa, 2018.

MACÊDO, Lucas Buril. Precedentes judiciais e o direito processual civil. Salvador: Juspodivm, 2014.

MANCKIEWICZ, René H. Le rôle de la jurisprudence et l'attitude du juge en pays de common law et en pays de droit écrit. Les Cahiers du Droit, v. 33, p. 18, 1954.

MARINONI, Luiz Guilherme. O precedente na dimensão da igualdade. In: MARINONI, Luiz Guilherme (Coord.) A força dos precedentes. Salvador: Juspodivm, 2010, p. 228-233.

MATA-MACHADO, Edgar de Godoi. Estudos de introdução à ciência do direito. Rio de Janeiro: Livraria AGIR, 1953.

MITCHELL, Léonie Marion. Le restatement aux États-Unis. Travaux Pratiques de Droit Privé Comparé. Paris: Institut du Droit Comparé de l’Université de Paris, 1936.

MITIDIERO, Daniel. Fundamentação e precedente - dois discursos a partir da decisão judicial. Revista de Processo, n. 206, p. 69, 2012.

NEVES, Antonio Castanheira. O instituto dos "assentos" e a função jurídica dos supremos tribunais. Coimbra: Coimbra Ed., 1983.

NUNES, Dierle; LACERDA, Rafaela; MIRANDA, Newton Rodrigues. O uso do precedente judicial na prática judiciária brasileira: uma perspectiva crítica. Revista da Faculdade de Direito da UFMG, n. 62, 2013.

PEIXOTO, Ravi de Medeiros. A posição dos tribunais superiores e a eficácia dos precedentes nas causas repetitivas Revista Dialética de Direito Processual, n. 119, p. 103-104, 2013. 
PORTUGAL. Constituição (1976). Constituição da República Portuguesa. Diário da República, Lisboa, 25 abr. 1976. Disponível em: https://www.parlamento.pt/Legislacao/

Paginas/ConstituicaoRepublicaPortuguesa.aspx. Acesso em: 2 maio 2020.

PORTUGAL. Lei n ${ }^{\circ}$ 41/2013, de 26 de Junho. Aprova o Código de Processo Civil. Diário da República, Lisboa, n. 121, Série I, 26 jun. 2013. Disponível em: https://dre.pt/home//dre/497406/details/maximized. Acesso em: 2 maio 2020.

SOUZA, Marcelo Alves Dias de. Do precedente judicial à súmula vinculante. 1. ed., 5. reimp. Curitiba: Juruá, 2011.

SOUZA, Marcus Seixas. Os precedentes judiciais e os assentos da Casa da Suplicação em Portugal: eficácia, vinculatividade e publicação. Revista de Processo, v. 268, p. 533-566, 2017.

STRECK, Lenio Luiz; ABBOUD, Georges. O que é isto: o precedente judicial e as súmulas vinculantes? Porto Alegre: Livraria do Advogado, 2013.

TARUFFO, Michele. Precedentes e jurisprudência. Revista de Processo, v. 199, 2011.

TEMER, Sofia. Incidente de resolução de demandas repetitivas: tentativa de sistematização. 2015. 135 f. Dissertação (Mestrado em Direito) - Universidade do Estado do Rio de Janeiro, Rio de Janeiro, 2015.

TUCCI, José Rogério Cruz e. Precedente judicial como fonte do direito. São Paulo: Revista dos Tribunais, 2004.

VENOSA, Sílvio de Salvo. Direito civil: parte geral. 3. ed. São Paulo: Atlas, 2003.

VERSOZA, Rafaela Leite. Análise comparativa entre Assentos e Súmula Vinculante: revisando o sentido da fonte jurisprudencial. $121 \mathrm{f}$. Dissertação (Mestrado em Ciências JurídicoFilosóficas) - Universidade de Coimbra, Coimbra, 2017.

WAMBIER, Teresa Arruda Alvim. A uniformidade e a estabilidade da jurisprudência e o Estado de Direito: civil law e common law. Revista Jurídica, n. 384, p. 59, 2009.

WAMBIER, Teresa Arruda Alvim. Interpretação da lei e de precedentes: civil law e common law. Revista dos Tribunais, v. 99 n. 893, p. 36, 2010.

ZANETI JÚNIOR, Hermes. O valor vinculante dos precedentes: teoria dos precedentes normativos formalmente vinculantes. 2. ed. rev. e atual. Salvador: JusPodivm, 2016. 